which they gave me, but it seemed to me that the appointments committee who had to choose three candidates from 150 applicants were more interested in these following three attributes than in the intended future career of the applicant: (i) Will he do the job well?; (ii) Can I work with him?; (iii) Is he committed to taking the MRCP with a fair chance of passing it?

Of the three of us appointed that day, one is in general practice, one is a registrar in medicine and I am a registrar in psychiatry; we all have the MRCP.

In conclusion, I take serious issue with Dr Thomas's contention that, 'If physicians are serious in their request that psychiatrists should have further experience then perhaps the two respective Colleges need to consider jointly the best method for achieving this.' Rather, if a trainee is serious in his intention to become well trained, then he needs to consider seriously the best method for achieving this himself.

R. LAWRENCE

Lucy Baldwin Hospital

Stourport on Severn, Worcs.

\section{Distinction awards in psychiatry}

DeAr SIRS

I would like to follow on from Professor Rawnsley's note about distinction awards in psychiatry (Bulletin, September $1985,9,187)$. Since I have been a member of the SE Thames Regional 'C' Awards Committee I have been disappointed at the number of psychiatrists put forward from the districts, and some years none have been proposed. It might be that few psychiatrists would be accepted even if names were forthcoming, but unless there are nominations I can do nothing to support deserving colleagues.

To my mind, an important reason for this state of affairs is the problem, unique to psychiatry, of the relationship of the large psychiatric hospitals to associated general hospitals. Many psychiatrists in the SE Thames Region still have the majority of their beds in a psychiatric hospital in one health district while their catchment area is likely to be in another. Thus, should they be proposed for an award by the district with the psychiatric hospital or the district containing the catchment area, where there are usually general hospital outpatient sessions? One can only suspect that, quite often, the consultant does not get proposed by either district. I believe this situation is overcome sometimes by a group of award holders at a particular psychiatric hospital taking the initiative and putting forward appropriate colleagues to one or other district awards subcommittee. Of course, if the psychiatric hospital has no award holders then this solution is not feasible.

These are difficulties that I perceive in relation to adult psychiatry. The problems seem worse for consultants in child psychiatry and, in my view, they are almost hopeless for consultants in mental handicap. But the reasons are similar. Mental handicap hospitals usually lack any relationship at all to general hospitals, and child psychiatrists tend to work in an individual way in the community, usually with some general hospital associations, but over a wide territory.

The regional awards committees also receive names from the regional officers and from the Royal Colleges, but these may not always have the same weight with the committee members as do the recommendations from their own body of working consultants.

I annually seek advice from the chairmen of the regional specialty subcommittees for child psychiatry and mental handicap, but even then these nominations have to be processed by relevant committees, and it is not always practicable to arrange this. I would be interested to know the views of awards committee colleagues in other regions. It may be that a national review of the situation is required.

Guys Hospital

Paul Bridges

London SEI

\section{'Tactical Exercises without Troops'}

\section{Dear Sirs}

My reading about the delivery of health care in the psychiatric services has covered a period of some 25 years. It has included, in my early days, literature on the day hospital movement; has passed through the reading of plans for the development of services (characteristically indicated as being without new resources-by analogy with what I learnt in the Army was called 'TEWT', that is, 'Tactical Exercises without Troops'); and is brought up to the present day by: 'Understanding the Italian experience' by Kathleen Jones and Alison Poletti; ' Rosalind Furlong's article in the Bulletin; ${ }^{2}$ and David Parfitt's article in the British Journal of Clinical and Social Psychiatry. ${ }^{3}$

It was not reading alone that led me to two axioms in psychiatric care, but also a holiday visit over several days to the city of what an 18th or 19th century writer would have called ' $W-$ ', and its pedestrian precincts, where I observed a lot of behaviour that has almost disappeared from my own long-stay wards.

The axioms are: (1) If a new type of resource is developed and funded this has no effect on the care of those whose need is greatest, and is most specifically for psychiatric as opposed to generally pastoral care; (2) If a new facility is developed without new resources, it is to the maximum detriment of those in maximum need.

I fear in the next decade or so that the fundamental, indeed, axiomatic nature of my second notion will be more frequently demonstrated than the first, but I would welcome a response both from those who agree and those who disagree with me before we have the benefit of hindsight.

\section{Highcroft Hospital}

B. H. FOOKES

Erdington, Birmingham

\section{REFERENCES}

I JONES, K. \& Polettr, A. (1985) Understanding the Italian experience. British Journal of Psychiatry, 146, 341-347.

2 Furlong, R. (1985) Closure of large mental hospitals: Practicable or desirable. Bulletin of the Royal College of Psychiatrists, 9, 130134.

3 PARfrtr, D. (1985) Asylum 1929. British Journal of Clinical and Social Psychiatry, 3, 3-5. 